\title{
PENGARUH PENGGUNAAN MATERIAL CETAK TERHADAP \\ WAKTU DAN BIAYA PROYEK PEMBANGUNAN \\ RUMAH SEJAHTERA TAPAK (RST)
}

\section{Product Innovation Effect Of Housing Housing Consumer Confidence To Developer (A Case Study Of Housing In Jember )}

\author{
Imam Wahyudi ${ }^{1}$, Ludfi Djakfar ${ }^{2}$, Arief Rachmansyah ${ }^{3}$ \\ ${ }^{1,2}$ Jurusan Teknik Sipil Universitas Brawijaya Malang \\ Jl. MT. Haryono No 167 Malang, Indonesia
}

\begin{abstract}
The purpose of this study was to determine the effect of the use of printed materials to the time and cost of development projects Tread Welfare House in Malang and determine the ratio of the time and expense. The method used to analyze the cost and time by using earmed value concept . Estimated completion of aspects of the schedule obtained approximate completion time (TE) was 70 days with the use of conventional materials, while using printed material is for 64 days. This case shows the project using print materials to accelerate approximately 8 days of the 72 -day plan . The conclusion of this study is the effect of the use of conventional materials based on the use of earned value schedule states that a plan with almost the same execution time by 72 days to 100 houses, while the performance in terms of cost, is effective for less than the cost of implementing the plan, so there are advantages Rp.72,396,667.04 amounted to 100 houses. While using print materials faster implementation 8 days from the time the plan is as much as 64 days to 100 houses, while the performance is analyzed in terms of costs with earned value concept can be assessed effectively with a gain of Rp.125,139,788.80 to 100 housing units .
\end{abstract}

Keywords : Home Prosperous Tread, Conventional Materials, Materials Print

\begin{abstract}
Abstrak
Adapun tujuan dalam penelitian ini adalah untuk mengetahui pengaruh penggunaan material cetak terhadap waktu dan biaya proyek pembangunan Rumah Sejahtera Tapak di kota Malang dan mengetahui perbandingan terhadap waktu dan biaya. Metode yang digunakan untuk menganalisis biaya dan waktu yaitu dengan menggunakan earmed value concept. Perkiraan penyelesaian dari aspek jadual didapat perkiraan waktu penyelesaian pekerjaan (TE) adalah 70 hari dengan menggunakan material konvensional, sedangkan menggunakan material cetak adalah sebesar 64 hari. Hal Ini menunjukkan proyek dengan menggunakan material cetak akan mengalami percepatan kurang lebih 8 hari dari waktu rencana 72 hari. Kesimpulan dalam penelitian ini adalah pengaruh penggunaan material konvensional berdasarkan penggunaan earned value schedule menyatakan bahwa waktu rencana dengan waktu pelaksanaan hampir sama yaitu sebesar 72 hari untuk 100 unit rumah, sedangkan kinerja dari segi biaya dinilai efektif karena biaya pelaksanaan lebih kecil dari rencana, sehingga ada keuntungan sebesar Rp.72,396,667.04 untuk 100 unit rumah. Sedangkan dengan menggunakan material cetak pelaksanaan lebih cepat 8 hari dari pada waktu rencana yaitu sebanyak 64 hari untuk 100 unit rumah, sedangkan kinerja dari segi biaya yang dianalisa dengan earned value concept dapat dinilai efektif dengan keuntungan sebesar Rp.125,139,788.80 untuk 100 unit rumah.
\end{abstract}

Kata Kunci : Rumah Sejahtera Tapak, Material Konvensional, Material Cetak

\section{PENDAHULUAN}

Perumahan merupakan salah satu kebutuhan yang sulit dijangkau oleh masyarakat miskin di Indonesia. Permasalahan utama yang dihadapi oleh masyarakat miskin adalah terbatasnya akses terhadap perumahan yang sehat dan layak, rendahnya mutu lingkungan permukiman dan lemahnya perlindungan untuk mendapatkan dan menghuni perumahan yang layak dan sehat.

Merujuk pada data Rencana Pembangunan Jangka Panjang Nasional (RPJPN 2005-2025), 
kebutuhan perumahan hingga tahun 2025 diperkirakan mencapai lebih dari 30 juta unit sehingga kebutuhan rumah baru diperkirakan mencapai 1,2 juta unit per tahun.

Pemerintah, melalui Kementerian Perumahan Rakyat (Kemenpera) memprogramkan pembangunan rumah murah khusus untuk PNS dan masyarakat berpenghasilan rendah (MBR) tipe 36 dengan menggunakan sistem cetak. Rumah cetak adalah rumah yang dibuat dengan rmenggunakan rangka besi dengan dinding dari cor beton. Kemenpera menyatakan bahwa rumah cetak tersebut murah serta hemat biaya dan waktu pengerjaannya serta secara struktur rumah cetak tersebut tahan gempa.

Kriteria perimbangan untuk pembangunan perumahan adalah meliputi rumah sederhana, rumah menengah dan rumah mewah dengan perbandingan sebesar 6 (enam) atau lebih, berbanding 3 (tiga), atau lebih, berbanding 1 (satu), sehingga dapat terwujud lingkungan hunian yang serasi yang dapat mengakomodasikan kelompok masyarakat dalam berbagai status sosial, tingkat ekonomi dan profesi. Pola hunian ini lebih dikenal dengan sebutan $1: 3: 6$ (Blaang,C,1986).

Mengingat banyaknya permintaan rumah RST oleh Masyarakat Berpenghasilan Rendah di wilayah Malang, maka perlu dilakukan pengkajian dan melihat pengaruh material cetak terhadap waktu dan biaya produksi. Selain itu, dilakukan berbagai sistem untuk pengadaan material dengan harapan dapat menghasilkan bangunan dengan mutu, waktu dan biaya yang tepat. Sistem yang telah digunakan oleh developer adalah sistem konvensional yaitu penggunaan material bata merah dan batako. Untuk sistem yang tengah dilakukan pada saat ini dengan menggunakan sistem on site yaitu pencetakan material dilakukan di lokasi sekitar pembangunan proyek sehingga memudahkan pendistribusian dan penggunaan material tanpa harus menunggu waktu pengiriman material dari supplier, selain itu akan dicoba pula menggunakan system cetak pabrikasi sehingga nantinya dapat diketahui manakah system yang efektif dalam menyelesaikan proyek 1000 unit RST tersebut.

Berdasarkan latar belakang dan identifikasi masalah, maka rumusan masalah dalam penelitian ini adalah :
- Bagaimanakah pengaruh penggunaan material konvensional terhadap waktu dan biaya proyek pembangunan Rumah Sejahtera Tapak (RST) di kota Malang ?

- Bagaimanakah pengaruh penggunaan material cetak terhadap waktu dan biaya proyek pembangunan Rumah Sejahtera Tapak di kota Malang ?

- Bagaimanakah perbandingan antara penggunaan material konvensional dengan material cetak terhadap waktu dan biaya proyek pembangunan Rumah Sejahtera Tapak di Kota Malang)?

Dalam penelitian ini dibuat pembatasan sebagai berikut :

- Penelitian ini hanya dibatasi pada pembangunan rumah sejahtera tapak (RST) dengan spesifikasi dan ketentuan pemerintah yang dilakukan oleh PT. X di wilayah kota Malang

- Penelitian menitik beratkan pada efektifitas penggunaan material konvensional dan material cetak yang tengah diterapkan oleh PT. X

- Bahwa material cetak yang dikembangkan oleh PT. X ini masih dalam tahap pengembangan dan uji coba maka akan terjadi penyesuain waktu dan biaya apabila diterapkan secara luas.

\section{METODE PENELITIAN}

\section{Lokasi Penelitian}

Adapun obyek dalam penelitian ini berada di Perumahan Bulan Terang Utama Kota Malang yang tengah melaksanakan pembangunan rumah sejahtera tapak (RST) dengan menggunakan material cetak. Proyek perumahan yang akan dibangun terletak di Kelurahan Madyopuro dan elurahan Lesanpuro, Kecamatan Kedungkandang Kota Malang.

\section{Teknik pengumpulan data}

- Observasi lapangan, yaitu melihat secara langsung dan mendokumentasikan pekerjaan pembangunan yang dilakukan di lapangan oleh pelaksana/mandor lapangan dan merekam metode yang telah dilaksanakan dengan membuat suatu isian pertanyaan yang diisi langsung oleh peneliti mengenai waktu dan biaya. 
- Wawancara dan kuisioner, melakukan studi berupa isian terhadap bagian teknik pengembang, berisi antara lain : harga bahan bangunan, harga borongan, harga tukang, analisa biaya dan lain-lain.

\section{Teknik analisis data}

Dalam penelitian ini, dua hal yang menjadi indicator penting yaitu waktu dan biaya proyek pembangunan rumah sejahtera tapak. Untuk mengukur pengaruh terhadap waktu ditinjau dari analisis varian dan kurva S. Sedangkan untuk menganlisis biaya digunakan pendekatan earned value concept adalah konsep menghitung besarnya biaya yang menurut anggaran sesuai dengan pekerjaan yang telah diselesaikan atau dilaksanakan (Soeharto,2005).Selain dengan metode tersebut adapun cara menganalisis dalam penelitian ini dengan menggunakan Earned Schedule Management (ES) merupakan perluasan teori dan praktek Earned Value Management (EVM) Sedangkan untuk menganlisis biaya digunakan pendekatan earned value concept adalah konsep menghitung besarnya biaya yang menurut anggaran sesuai dengan pekerjaan yang telah diselesaikan atau dilaksanakan (Soeharto,2005).

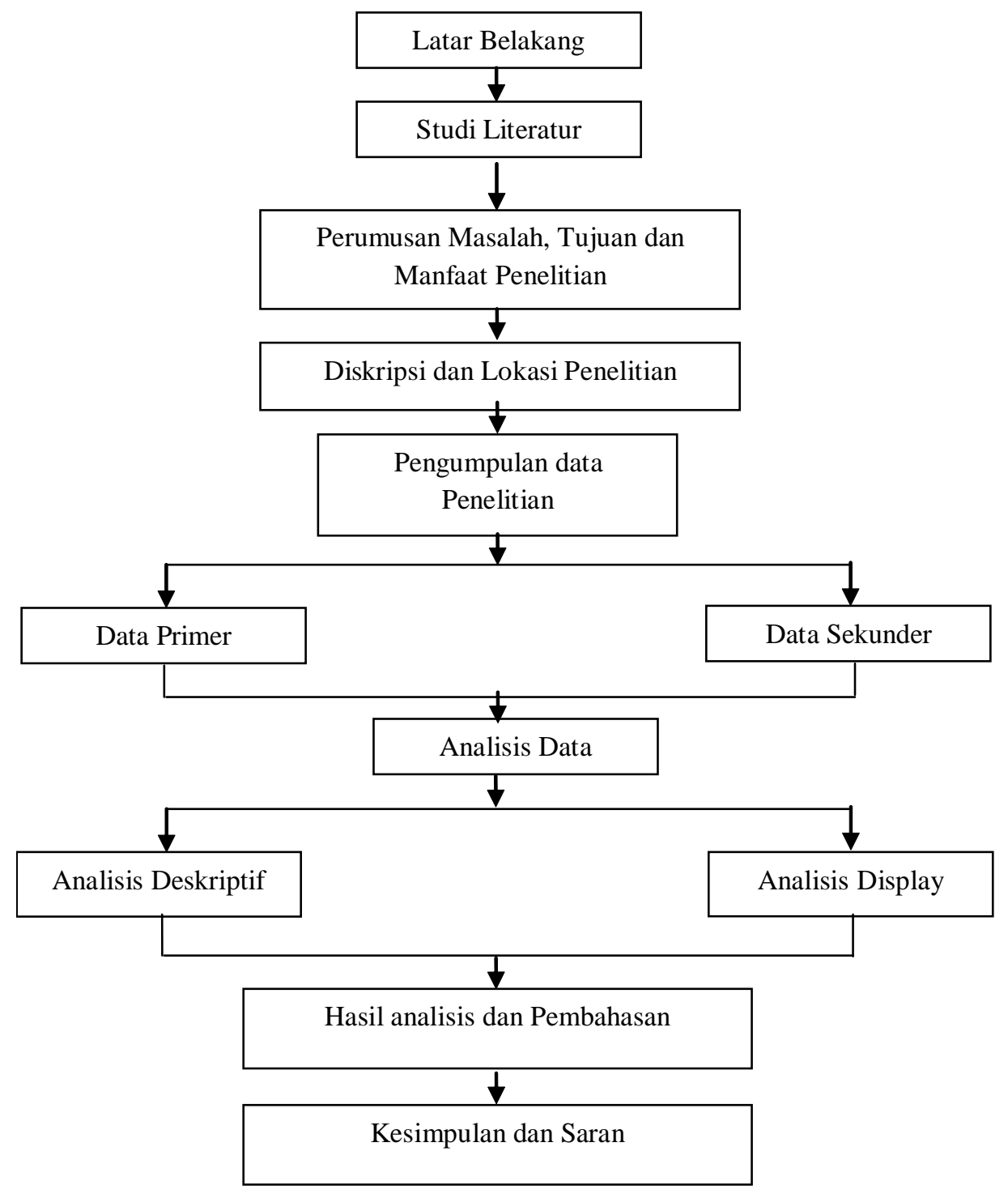

Gambar 1. Diagram Alur Penelitian

\section{HASIL DAN PEMBAHASAN Analisa biaya dan waktu}

Analisa biaya dan waktu pada penelitian ini yaitu dengan menggunakan Earned Value Concept pada proyek Proyek Pembangunan Rumah Sejahtera Tapak yang menggunakan material konvensional 
Tabel 1. Hasil Observasi dan wawancara

\begin{tabular}{|c|c|c|}
\hline $\begin{array}{r}\text { OBSERVASI DAN } \\
\text { WAWANCARA }\end{array}$ & MATERIAL KONVENSIONAL & MATERIAL CETAK \\
\hline stor Kesulitan & $\begin{array}{l}\text { Material sering terlambat dalam } \\
\text { pengiriman } \\
\text { dalitas material tidak sama. } \\
\text { ktor pekerja yang sering tidak masuk } \\
\text { aca (hujan) sangat berpengaruh } \\
\text { terhadap pelaksanaan }\end{array}$ & $\begin{array}{l}\text { Ienggunakan alat berat } \\
\text { Membutuhkan modal awal yang } \\
\text { cukup besar } \\
\text { 'erlu dilakukan penjelasan kepada } \\
\text { pekerja/pengetahuan tentang } \\
\text { cetak beton }\end{array}$ \\
\hline ktor Kelebihan & $\begin{array}{l}\text { udah pengerajaannya karena pekerja } \\
\text { telah terbiasa }\end{array}$ & $\begin{array}{l}\text { Kualitas material di semua } \\
\text { bangunan relative sama } \\
\text { tktu lebih cepat } \\
\text { dalitas bangunan baik } \\
\text { aya lebih murah bila dibangun } \\
\text { banyak / lebih dari } 100 \text { unit. }\end{array}$ \\
\hline
\end{tabular}

\section{Perhitungan BCWS pada Rumah Sejahtera Tapak dengan Material Batako}

Dalam penelitian ini, BCWS dihitung dengan melihat jadwal rencana berdasarkan kurva harian proyek atau dalam 30 hari pengerjaan untuk satu unit rumah sejahtera tapak dengan material batako. BCWS minggu ke-1\% komulatif progress rencana minggu pertama sebesar $14,65 \%$

Anggaran biaya rencana $=$ Rp. $24.842 .724,26$

$\mathrm{BCWS}=\%$ komulatif progress rencana $\mathrm{x}$ Nilai

$$
\text { Kontrak }
$$$$
=14,65 \% \text { x Rp. Rp. } 24 \cdot 842 \cdot 724,26
$$$$
=\text { Rp. 3.636.975,- }
$$

Tabel 2. Perhitungan Nilai BCWS Pembangunan 1 Unit Rumah Sejahtera Tapak Material Batako

\begin{tabular}{ccc}
\hline $\begin{array}{c}\text { Minggu } \\
\text { ke }\end{array}$ & $\begin{array}{c}\text { \% Komulatif } \\
\text { rencana }\end{array}$ & $\begin{array}{c}\text { Nilai BCWS } \\
(\mathrm{Rp})\end{array}$ \\
\hline 1 & 14,65 & 3.636 .975 \\
2 & 3,232 & 6.533 .636 \\
3 & 41,13 & 10.217 .812 \\
4 & 71,42 & 17.742 .674 \\
\hline
\end{tabular}

\section{Perhitungan BCWP pada rumah sejahtera tapak dengan material batako}

Nilai hasil (Earned Value) atau BCW S adalah hasil yang didapat berdasarkan pekerjaan yang telah terselesaikan, dianggarkan dari pekerjaan yang telah diselesaikan. Nilai hasil dihitung berdasarkan persentase bobot yang didapat dikalikan dengan total anggaran (nilai kontrak).

Perhitungan BCWP pada minggu ke-1

$\%$ komulatif progress realisasi minggu ke- $1=14,65$ $\%$

142| Agustus 2014, Hal. $139-148$
Nilai kontrak $=$ Rp. $24,842,724.26$

$\mathrm{BCWP}=\%$ komulatif progress realisasi $\mathrm{x}$ Nilai Kontrak $=14,65 \%$ X R. $24,842,724.26$ $=$ Rp. 3,639,459.10

Tabel 3. Perhitungan Nilai BCWP Pembangunan 1 Unit Rumah Sejahtera Tapak Material Batako

\begin{tabular}{lll}
\hline $\begin{array}{c}\text { Minggu } \\
\text { ke }\end{array}$ & $\begin{array}{c}\text { \%Komulatif } \\
\text { rencana }\end{array}$ & \multicolumn{1}{c}{$\begin{array}{c}\text { Nilai BCWP } \\
(\mathrm{Rp})\end{array}$} \\
\hline 1 & 14,65 & $3,639,459.10$ \\
2 & 26,88 & $6,677,724.28$ \\
3 & 43,17 & $10,724,604.06$ \\
4 & 92,73 & $23,036,658.21$ \\
\hline
\end{tabular}

\section{Perhitungan Actual Cost (EV) atau ACWP}

Perhitungan Actual Cost diperoleh dari laporan harian, mingguan dan bulanan. Dalam hal ini volume pekerjaan actual dikalikan dengan harga satuan pekerjaan, sehingga nilai tersebut sudah termasuk biaya langsung yaitu biaya material, biaya tenaga kerja dan biaya peralatan.

Tabel 4 Perhitungan nilai ACWP Pembangunan 1 Unit Rumah Sejahtera Tapak Material Batako

\begin{tabular}{ll}
\hline $\begin{array}{c}\text { Minggu } \\
\text { Ke- }\end{array}$ & $\begin{array}{c}\text { Nilai Actual } \\
\text { Cost/ACWP (Rp) }\end{array}$ \\
\hline 1 & $4,549,075.47$ \\
2 & $8,332,746.52$ \\
3 & $13,355,075.87$ \\
4 & $28,266,424.34$
\end{tabular}


Analisis Kinerja Biaya dan Waktu Proyek Saat Pelaporan

Berdasarkan hasil perhitungan BCWP, BCWS dan ACWP dapat diketahui kinerja proyek yaitu biaya dan waktu saat pelaporan. Untuk mengetahui kinerja biaya dapat dilihat dari besarnya nilai Varian Biaya/Cost Varian Sedangkan untuk mengetahui kinerja waktu dapat dilihat dari besarnya nilai Varian Jadwal/Schedule Varians (SV), yang diformulasikan sebagai berikut :

Varian Biaya $(\mathrm{CV})=$ BCWP-ACWP

Varian Jadwal $(\mathrm{SV})=\mathrm{BCWP}-\mathrm{BCWS}$

Berikut nilai CV dan SV pada proyek pembangunan rumah sejahtera tapak dengan menggunakan material batako dapat dilihat pada Tabel 5 dan Tabel 6.

Tabel 5. Perhitungan nilai varian Biaya (CV) Pembangunan 1 Unit Rumah Sejahtera Tapak Material Batako

\begin{tabular}{cccc}
\hline Minggu ke & BCWP & ACWP & Nilai Varian Biaya $(\mathrm{CV})=$ BCWP-ACWP \\
\hline 1 & $3,639,459.10$ & $4,020,030.00$ & $-380,570.90$ \\
2 & $6,677,724.28$ & $6,507,500.00$ & $170,224.28$ \\
3 & $10,724,604.06$ & $10,659,000.00$ & $65,604.06$ \\
4 & $23,036,658.21$ & $23,005,000.00$ & $31,658.21$ \\
\hline
\end{tabular}

Tabel 6. Perhitungan nilai Varian Jadwal(SV) Pembangunan 1 Unit Rumah Sejahtera Tapak Material Batako

\begin{tabular}{cccc}
\hline inggu ke & BCWP & BCWS & Nilai Varian Jadwal (SV)= BCWP-BCWS \\
\hline 1 & $3,639,459.10$ & $3,636,975.00$ & $2,484.10$ \\
2 & $6,677,724.28$ & $6,533,636.00$ & $144,088.28$ \\
3 & $10,724,604.06$ & $10,217,812.00$ & $506,792.06$ \\
4 & $23,036,658.21$ & $22,200,674.00$ & $835,984.21$ \\
\hline
\end{tabular}

Berdasarkan Tabel 6 dan 7 tersebut dapat dilihat status proyek saat pelaporan pada minggu k1 atau saat awal pelaksanaan proyek menunjukkan SV bernilai Positif dan CV bernilai negatif, dimana berdasarkan analisis varians terpadu pada bab II telah dijelaskan bahwa apabila SV bernilai Positif dan CV bernilai negatif menunjukkan bahwa proyek pada saat pelaporan Pekerjaan lebih cepat dari jadwal, biaya lebih tinggi dari Anggaran. Berdasarkan pengamatan dilapangan, analisis tersebut dapat dikatakan sesuai karena pada awal proyek nilai yang digunakan cukup besar untuk pekerjaan persiapan dan pengadaan alat kerja. Namum untuk minggu ke dua hingga minggu ke empat selesainya pekerjaan nilai SV dan CV bernilai positif hal ini menandakan bahwa pada pekerjaan lebih cepat dari jadwal dengan biaya kurang dari anggaran.

\section{Analisa Earned Schedule Manajemen (ES) untuk Mengetahui Efesiensi Sumber Daya.}

Adapun perhitungan nilai CPI pada pembangunan 1 unit RST dengan material batako dapat dilihat pada Tabel 7

Tabel 7. Perhitungan nilai CPI Pembangunan 1 Unit Rumah Sejahtera Tapak Material Batako

\begin{tabular}{cccc}
\hline Minggu ke & BCWP & ACWP & CPI = BCWP/ACWP \\
\hline 1 & $3,639,459.10$ & $4,020,030.00$ & 0.91 \\
2 & $6,677,724.28$ & $6,507,500.00$ & 1.03 \\
3 & $10,724,604.06$ & $10,659,000.00$ & 1.01 \\
4 & $23,036,658.21$ & $23,005,000.00$ & 1.00 \\
\hline
\end{tabular}


Tabel 8. Perhitungan nilai SPI Pembangunan 1 Unit Rumah Sejahtera Tapak Material Batako

\begin{tabular}{cccc}
\hline Minggu ke & BCWP & BCWS & SPI= BCWP/BCWS \\
\hline 1 & $3,639,459.10$ & $3,636,975.00$ & 1.00 \\
2 & $6,677,724.28$ & $6,533,636.00$ & 1.02 \\
3 & $10,724,604.06$ & $10,217,812.00$ & 1.05 \\
4 & $23,036,658.21$ & $17,742,674.00$ & 1.30 \\
\hline
\end{tabular}

Pengaruh penggunaan material konvensional terhadap waktu dan biaya proyek pembangunan Rumah Sejahtera Tapak (RST)
Adapun hasil analisa biaya dan waktu berdasarkan earned value concept dengan melihat nilai CPI dan SPI dapat dilihat dalam Tabel 9.

Tabel 9. CPI dan SPI rumah sederhana tapak dengan metode konvensional (batako)

\begin{tabular}{cccl}
\hline Minggu ke & CPI & SPI & \multicolumn{1}{c}{ Keterangan Analisa } \\
\hline 1 & 0.91 & 1.00 & $\begin{array}{l}\text { Kurang dari 1 kinerja penyelengaraan proyek kurang baik, pengeluaran } \\
\text { lebih besar dari rencana dan waktu pelaksanaan lebih banyak dari jadwal } \\
\text { rencana(terlambat) }\end{array}$ \\
2 & 1.03 & 1.02 & $\begin{array}{l}\text { Lebih dari 1 kinerja penyelengaraan proyek baik, kerena pengeluaran } \\
\text { lebih kecil dari rencana dan waktu pelaksanaan lebih sedikti dari jadwal } \\
\text { rencana } \\
\text { Lebih dari 1 kinerja penyelengaraan proyek baik, kerena pengeluaran } \\
\text { lebih kecil dari rencana dan waktu pelaksanaan lebih sedikti dari jadwal } \\
\text { rencana } \\
\text { Lebih dari 1 kinerja penyelengaraan proyek baik, kerena pengeluaran } \\
\text { lebih kecil dari rencana dan waktu pelaksanaan lebih sedikti dari jadwal } \\
\text { rencana }\end{array}$ \\
\hline
\end{tabular}

Tabel 10. Perbandingan biaya dan waktu berdasarkan kondisi eksisting dengan hasil analisa

\begin{tabular}{cccl}
\hline Minggu ke & $\begin{array}{c}\text { BIaya Rencana } \\
(\mathrm{Rp})\end{array}$ & $\begin{array}{c}\text { Biaya Aktual } \\
(\mathrm{Rp})\end{array}$ & \multicolumn{1}{c}{ Keterangan } \\
\hline 1 & $3,639,459.10$ & $4,020,030.00$ & Biaya aktual lebih besar dari rencana \\
2 & $6,677,724.28$ & $6,507,500.00$ & Biaya aktual lebih kecil dari rencana \\
3 & $10,724,604.06$ & $10,659,000.00$ & Biaya aktual lebih kecil dari rencana \\
4 & $23,036,658.21$ & $23,005,000.00$ & Biaya aktual lebihkecil dari rencana \\
\hline
\end{tabular}

Pengaruh Penggunaan Material Cetak Terhadap Waktu dan Biaya Proyek Pembangunan Rumah Sejahtera Tapak (RST)

Pengaruh penggunaan material cetak terhadap waktu dan biaya proyek pembangunan sejahtera tapak (RST) berdasarkan analisa dengan menggunakan Earned Value Concept dan Earned Schedule. Analisa penggunaan material menggunakan material cetak, dalam penelitian ini pengembang menjadikan system cetak ini sebagai salah satu alternative pembangunan RST dengan mutu, waktu dan biaya yang tepat. Sistem ini dilakukan dengan cara pengecoran komponen di tempat khusus di permukaan tanah (fabrikasi), lalu dibawa ke lokasi (transportasi ) untuk disusun menjadi suatu struktur utuh (ereksi)

Dari hasil penelitian dengan menggunakan earned value concept di dapatkan pengaruh biaya dan waktu pelaksanaan dengan menggunakan system batako secara keseluruhan sesuai dengan kondisi sesungguhnya di lapangan. Dalam penelitian ini, analisa di lakukan per 1 unit rumah dengan rencana pengerjaan selama 30 hari.

Adapun hasil analisa biaya dan waktu berdasarkan earned value concept dengan melihat nilai CPI dan SPI dapat dilihat dalam Tabel 11 
Tabel 11 analisa biaya dan waktu berdasarkan CPI dan SPI rumah sederhana tapak dengan metode cetak

\begin{tabular}{cccl}
\hline $\begin{array}{c}\text { Minggu } \\
\text { ke }\end{array}$ & CPI & SPI & \multicolumn{1}{c}{ Keterangan Analisa } \\
\hline 1 & 0.91 & 2.11 & $\begin{array}{l}\text { CPI kurang dari 1 yang menandakan pengeluaran lebih besar dari rencana } \\
\text { dan SPI lebih besar dari 1 yang berarti progress actual lebih besar daripada } \\
\text { rencana }\end{array}$ \\
2 & 1.09 & 1.36 & $\begin{array}{l}\text { pengeluaran lebih kecil dari rencana dan waktu pelaksanaan lebih sedikit dari } \\
\text { jadwal rencana }\end{array}$ \\
3 & 1.06 & 1.18 & $\begin{array}{l}\text { pengeluaran lebih kecil dari rencana dan waktu pelaksanaan lebih sedikti dari } \\
\text { jadwal rencana } \\
\text { pengeluaran lebih kecil dari rencana dan waktu pelaksanaan lebih sedikti dari } \\
\text { jadwal rencana. }\end{array}$ \\
4 & 1.05 & 1.01 & \\
\hline
\end{tabular}

Adapun analisa biaya dan waktu dengan kondisi excisting (dilapangan) dengan melihat laporan mingguan dan laporan akutansi proyek

dengan pengamatan langsung dapat dilihat pada Tabel 12

Tabel 12. Perbandingan biaya berdasarkan kondisi eksisting rumah sederhana tapak dengan menggunakan material konvensional(cetak)

\begin{tabular}{cccl}
\hline Minggu ke & $\begin{array}{c}\text { Biaya Rencana } \\
(\mathbf{R p})\end{array}$ & $\begin{array}{c}\text { Biaya Aktual } \\
(\mathbf{R p})\end{array}$ & Keterangan \\
\hline 1 & $7,198,224.05$ & $8,918,046.45$ & Biaya actual lebih besar dari rencana \\
2 & $12,976,662.05$ & $11,938,529.08$ & Biaya actual lebih kecil dari rencana \\
3 & $17,930,338.18$ & $16,854,517.89$ & Biaya actual lebih kecil dari rencana \\
4 & $23,286,153.48$ & $22,121,845.81$ & Biaya actual lebih kecil dari rencana \\
\hline
\end{tabular}

Adaupun perbandingan waktu berdasarkan kondisi eksisting rumah sederhana tapak dengan

menggunakan material konvensional(cetak) dapat dilihat pada Tabel 13.

Tabel 13. Perbandingan waktu berdasarkan kondisi eksisting rumah sederhana tapak dengan menggunakan material konvensional(cetak).

\begin{tabular}{clll}
\hline Minggu ke & $\begin{array}{l}\text { Progress } \\
\text { rencana }\end{array}$ & $\begin{array}{l}\text { Progress } \\
\text { aktual }\end{array}$ & \multicolumn{1}{c}{ Keterangan } \\
\hline 1 & $14,67 \%$ & $30,91 \%$ & $\begin{array}{l}\text { Waktu pelaksanaan lebih cepat dari rencana dan progress actual lebih } \\
\text { besar dari rencana } \\
2\end{array}$ \\
$40,84 \%$ & $55,73 \%$ & $\begin{array}{l}\text { Terjadi percepatan waktu dibandingkan dengan waktu rencana } \\
\text { Terjadi percepatan penyelesaian pekerjaan dibandingkandengan } \\
\text { waktu rencana }\end{array}$ \\
\hline
\end{tabular}

Dari kedua tabel tersebut, didapatkan untuk minggu pertama yaitu hari ke 1-7 nilai CPI yaitu sebesar 0,91 yang berarti nilai biaya yang dikeluarkan melebihi biaya rencana awal, karena pada minggu pertama terjadi pembengkakan biaya untuk pekerjaan persiapan dan peralatan produksi yaitu transporatsi dan ereksi untuk system cetak. Hal ini diperkuat oleh data lapangan yang tertera dalam laporan akutansi proyek. Namun untuk nilai SPI sebesar 2,11 hal ini menandakan progress pelaksanaan lebih besar dari perencanaan. Hal ini sesuai dengan kondisi dilapangan,dimana system cetak pada dasarnya dilakukan pengecoran komponen di tempat khusus di permukaan tanah (fabrikasi), lalu dibawa ke lokasi (transportasi )

Pada minggu ke dua berdasarkan analisa didapatkan progress pelaksananaan jauh lebih besar dari rencana, dikarenakan nilai CPI dan SPI berada diatas 1 , yang menandakan kinerja penyelengaraan proyek sangat baik, yaitu pengeluaran lebih kecil dari rencana dan waktu pelaksanaan lebih sedikit atau mengalami percepatan

Pada minggu ketiga proyek berdasarkan anaisa earned value, progress pelaksanaan pekerjaan lebih besar dari pada rencana dan biaya yang dikeluarkan lebih sedikit dari biaya rencana hal ini ditunjukkan oleh nilai CPI 1,06 dan SPI 1,11 Pada kenyataan di 
lapangan progress pelaksaan lebih besar dari rencana, karena segala proses pelaksanaan dengan system cetak dilakukan on side tanpa terjadi keterlambatan waktu akibat keterlambatan pengiriman barang.

Minggu ke empat pelaksanaan berdasarkan analisa progress pelaksanaan lebih besar dari progress rencana. Pada minggu keempat sesuai dengan kondisi excisting proyek, progress pelaksanaan lebih besar dari progress rencana dan waktu untuk penyelesaian proyek lebih kecil dari rencana, yaitu waktu rencana sebesar 30 hari kerja sedangkan waktu actual sebesar 20 hari, hal ini menunjukkan bahwa ada penghematan waktu sebesar 10 hari dengan biaya yang dikeluarkan lebih kecil dari anggaran atau dengan kata lain terdapat keuntungan.

\section{Perbandingan Antara Penggunaan Material Konvensional dengan Material Cetak Terhadap Waktu dan Biaya Proyek Pembangunan Rumah Sejahtera Tapak Di Kota Malang}

Adapun perbandingan hasil analisa waktu dan biaya dengan menggunakan earned value dan earned schedule pada material konvensional dan cetak dapat dilihat pada Tabel 14

Tabel 14. Perbandingan hasil analisa waktu dan biaya dengan menggunakan earned value dan earned schedule pada material konvensional dan cetak

\begin{tabular}{ccc}
\hline Faktor Pembanding & Material Konvensional & Material Cetak \\
\hline Nilai CV & $835,984.21$ (bertanda +$)$ & $1,164,307,67$ (bertanda + ) \\
Nilai SV & $31,658.21$ (beranda + ) & $338,603.33$ (bertanda + ) \\
Nilai CPI & 1,00 ( sama dengan 1) & 1,05 ( lebih dari 1 \\
Nilai SPI & $1,03($ Lebih besar dari 1) & 1,05 (lebih dari 1) \\
Harga rencana 1 unit & Rp.27,326,996.69 & RP. 25,614,768,83 \\
$\quad$ Waktu Rencana \\
(untuk 1 unit RST) & 30 hari & 30 hari \\
$\begin{array}{l}\text { Waktu Penyelesaian } \\
\text { (untuk 1 unit RST) }\end{array}$ & 30 hari & 20 hari \\
Jilai ETC (100unit) 50\% & $1,277,661,308.78$ & $1,077,217,459.98$ \\
Nilai EAC (100unit) & $2,411,875,759.13$ & $2,203,475,559.20$ \\
E (prediksi penyelesaian) & 70 hari & 64 hari \\
100 unit & &
\end{tabular}

Dari Tabel 14 dapat diketahui material konvensional dan material cetak memiliki nilai Cost variance $(\mathrm{CV})$ positif yang menunjukkan bahwa progress pelaksanaan paket pekerjaan lebih besar dari pada rencana sehingga biaya yang dikeluarkan lebih besar daripada rencana. Dari tabel diketahui material cetak nilai CV lebih besar dibandingkan material konvensional, hal ini berarti progress pelaksanaan dan biaya yang dikeluarkan lebih besar dibandingkan dengan progress rencana.Schedule variance (SV) pada material konvensional dan material cetak bertanda positif yang menunjukkan bahwa paket-paket pekerjaan proyek yang terlaksana lebih banyak dibanding rencana.

Nilai CPI dan SPI baik material cetak maupun material konvensional lebih dari 1 , hal ini menunjukkan efisiensi kinerja waktu dan biaya secara keseluruhan dapat dikatakan baik dan sesuai dengan yang diharapkan, karena pekerjaan mampu diselesaiakan sesuai dengan target.

Nilai ETC pada material konvensional untuk pengerjaan 100 unit rumah menunjukkan nilai perkiraan biaya untuk pekerjaan tersisa dengan asumsi bahwa kecendrungan kinerja proyek akan tetap sampai dengan akhir proyek adalah sebesar Rp. 1,277,661,308.78 sedangkan perkiraan biaya yang dikeluarkan hinga proyek selesai (EAC) adalah sebesar Rp. 2,411,875,759.13 yang berarti ada keuntungan atau masih dibawah rencana anggaran (PV) yaitu sebesar Rp.72,396,667.04

Sedangkan nilai ETC pada material cetak menunjukkan perkiraan biaya untuk pekerjaan tersisa 
dengan asumsi bahwa kecendrungan kinerja proyek akan tetap sampai dengan akhir proyek (ETC) adalah sebesar Rp. 1,077,217,459.98 sedangkan perkiraan biaya yang dikeluarkan hinga proyek selesai (EAC) adalah sebesar Rp .2,203,475,559.20 yang berarti ada keuntungan atau masih dibawah rencana anggaran (PV) yaitu sebesar Rp 125,139,788.80. sehingga antara material konvensional dan material cetak memiliki selisih keuntungan sebesar Rp. 52.743.127,76,-

Perkiraan penyelesaian dari aspek jadual didapat perkiraan waktu penyelesaian pekerjaan (TE) adalah 70 hari dengan menggunakan material konvensional, sedangkan menggunakan material cetak adalah sebesar 64 hari. Hal Ini menunjukkan proyek dengan menggunakan material cetak akan mengalami percepatan kurang lebih 8 hari dari waktu rencana 72 hari.

\section{KESIMPULAN DAN SARAN}

\section{Kesimpulan}

- $\quad$ Pengaruh penggunaan material konvensional pada proyek pembanguan rumah sejahtera tapak (RST) terhadap waktu berdasarkan analisa earned value schedule menyatakan bahwa waktu rencana dengan waktu pelaksanaan hampir sama yaitu sebesar 72 hari untuk 100 unit rumah, sedangkan kinerja dari segi biaya dapat dinilai efektif karena biaya pelaksanaan lebih kecil dari rencana, sehingga ada keuntungan sebesar Rp.72,396,667.04 untuk 100 unit rumah.

- $\quad$ Sedangkan hasil analisis dengan material cetak menyatakan bahwa waktu pelaksanaan lebih cepat 8 hari dari pada waktu rencana yaitu sebanyak 64 hari untuk 100 unit rumah, sedangkan kinerja dari segi biaya ada keuntungan sebesar Rp.125,139,788.80 untuk 100 unit rumah.

- Perbandingan antara penggunaan material konvensional dengan material cetak dapat dikatakan rumah cetak memiliki kinerja dan efektivitas yang lebih baik dibandingkan dengan material konvensional karena terjadi penghematan waktu dan biaya pelaksanaan namun mutu dan kualitas yang diperoleh sesuai dengan standar yang ditetapkan.

\section{Saran}

- $\quad$ Studi tentang teknologi cetak harus terus dikembangkan karena mengingat system ini lebih efektif sehingga dapat digunakan sebagai alternatif produksi rumah sejahtera tapak dalam skala besar.

- Dalam pengendalian biaya proyek pembangunan rumah sejahtera tapak sebaiknya data-data perencanaan dan pelaksanaan yang dimiliki harus secara detail dan rinci agar nantinya dapat menjadi histori yang dapat digunakan sebagai acuan-acuan proyek berikutnya.

- Sebaiknya dalam pelaksanaan pembangunan RST perlu dilakukan pendekatan analisis di awal, pertengahan dan akhir proyek sengan pendekatan Earned value concept dan earned value schedule sehingga diketahui efektivitas kerja sehingga mutu, waktu dan biaya dapat terlaksanan dengan baik.

\section{DAFTAR PUSTAKA}

Blaang, C, D. 1986. Perumahan Dan Pemukiman Sebagai Kebutuhan Pokok. Yayasan Obor Indonesia. Jakarta

Budi Harjo, E. 2002. Sejumlah Masalah Pemukiman Kota. City Planning Indonesia. Jakarta Dennis Lock dan Jasfi E Manajemen Proyek, Edisi ketiga, Jakarta : Penerbitan Erlangga.

Hastria, Nurul. 2010. Faktor-Faktor yang Mempengaruhi Keputusan Masyarakat untu Memilih Tinggal di Kawasan Perumahan. Tesis Fakultas Ekonomi Universitas Sebelas Maret Surakarta.

Istimawan Dipohusodo, 1996, Manajemen Proyek dan Kontruksi, Jilid 1 dan 2, Yogyakarta: Penerbit Konisius.

Irika Widiastuti \& Lenggogeni, 2013. Manajemen Konstruksi. Bandung : PT. Remaja Rosdakarya

Mukomoko JA., 1985, Dasar Penyusunan Anggaran Biaya Bangunan, Jakarta: Radar Offset.

Republik Indonesia. 1992. Undang-undang No 4 Tahun 1992 Tentang Perumahan dan Kawasan Pemukiman. Sekretariat Negara. Jakarta.

Republik Indonesia. 2011. Undang-undang No 1 Tahun 2011 Tentang Perumahan dan Kawasan Pemukiman. Sekretariat Negara. Jakarta 
Santoso, B. 2000. Real Estate Sebuah Ilmu Dan Problema Pengembang Indonesia. School Of Real Estate. Jakarta

Peraturan Menteri Perumahan Rakyak Republik Indonesia Nomor 10 Tahun 2012 tentang Penyelenggaran Perumahan dan Kawasan PErmukiman dengan Hunian Berimbang.

Peraturan Menteri Perumahan Rakyak Republik Indonesia Nomor 13 Tahun 2012 tentang Pengadaan Perumahan Melalui Kredit/ Pembiayaan Pemilikan Rumah Sejahtera dengan Dukungan Fasilitas Likuiditas Pembiayaan Perumahan Perumahan.

Wulfram I.Ervianto. 2005. Manajemen Proyek Konstruksi. Yogayakarta : Penerbit ANDI 